\title{
震焱後の安全確認に用いる鋼構造梁端部破壊確率のベイズ更新 BAYESIAN UPDATING OF FAILURE PROBABILITY OF BEAM-TO-COLUMN CONNECTIONS FOR POST-EARTHQUAKE INSPECTION OF STEEL FRAMES
}

\author{
日下彰宏*, 岡野 創**, 中島正愛*** \\ Akihiro KUSAKA, Hajime OKANO and Masayoshi NAKASHIMA
}

\begin{abstract}
This study proposes a formulation for applying Bayesian updating for safety inspection of steel frames suffered from strong ground motion in which beam-to-column connections are potentially fractured. In the proposed method, probability distributions of deformation demand and capacity of connections are modeled as that their variations are divided into those of the average error as whole building, and those of deviations from the average. Then, Bayesian updating is applied for the former alone. In order to use for the proposal method, the variations in demand and capacity of connections are examined. For demand, MCS (Monte Carlo simulation) for time history analysis shows that the variation of the maximum rotation at beam-to-column connections is estimated to be 12 to $14 \%$ as logarithm standard deviation. For capacity, about $20 \%$ as logarithm standard deviation is statistically estimated from past structural tests for cumulative plastic deformation ratio. Finally, an MCS for a 9-story plan frame is presented as an illustrative example to examine the accuracy of the proposed method.
\end{abstract}

Keywords : Earthquake Disaster, Steel Structure, Safety Inspection, Bayesian Updating, Randomness 震災, 鋼構造, 安全確認, ベイズ更新, ばらつき

\section{1. はじめに}

大都市には多数の建物が集中しており, 地震後に安全を確認でき る構造技術者が不足することで速やかな建物の再利用を阻害される 可能性が指摘されている 1 )。

これに対し, 二次被害防止の観点からの応急対応として, 建物全 体としての被災度を判定する震災直後の応急判定マニュルアル 2)な どが整備されている。また, いわゆる地震モニタリングやシステム 同定により建物の損傷を検知寸る研究 3) $^{\text {) }}$ なども進められているが， 局所的な損傷部位を正確に特定できる段階には至っていない 7)。そ こで現状では, これらの技術を補完する意味でも, 構造技術者が実 物を確認する余地が残されているが, とくに鋼構造建物では, 仕上 げや耐火被覆が躯体を覆っているため, 目視確認には相当の費用や 時間が必要であり，できるだけ少ない検査箇所で建物の安全を確認 できる方法や検查すべき範囲の判断基準を構築することが望まれる。

構造物の検查戦略に関する既往研究は, 残余リスクに基づく検査

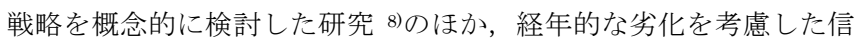
頼性解析 9), 検査結果を利用して劣化曲線を更新して検查計画を修 正する研究 10)などが行われてきた。文献 10 では, 検查を効率的に 進めるために, 一部の検查結果を利用して未検查範囲の破壊確率を ベイズ更新して，その後の検查計画を反映する方法が提案されてい
る。

地震被害に関連しては, 被害調查の結果を利用してフラジリティ 曲線のパラメタをベイズ更新する研究 ${ }^{11)}$, 情報の多骞や詳細さを考 慮してフラジリティ曲線のパラメタを更新する研究 12)がある。また, こうした構造体としての破壊確率を対象とする研究のほか，破壊位 置を特定するために, 非破壊試験の結果を利用して剛性などの構造 パラメタを更新する研究 13) もあるが，建物の部材レベルの破壊を 記述できる自由度の高いモデルは開発の途上である。

これらの既往の研究に対して, 本研究では, 構造技術者による現 地検査を支援するため, より少ない検査で建物の安全を確認するた めの検査戦略を構築することを目標とする。

本報では，鋼構造建物の梁端部の破断の有無を確認するために各 梁端の目視検查を実施する状況を想定し, その検查過程において, 既検査部位の結果を反映して, 検查部位の破壊確率を更新する方法 を定式化する。その際, 何らかの方法で部材の最大応答と変形能力 が推定されていることを前提とするが，検查結果に応じたその後の シナリオを予設定しやすいように, 既往研究 11)のように予測モデ ルそのものを更新して構造解析をやり直すことはせずに, 予測值と 真值の比をモデル化した確率変数の母数をベイズ更新する手法を検 討する。また，この検討に用いるために，平面骨組の地震応答解析

\footnotetext{
本研究は，文献27)で発表した研究に新たな検討を加えて加筆したものである。

* (株)小堀鐸二研究所 工修

** (株)小堀鐸二研究所 博士 (工学)

*** 京都大学防災研究所 教授. Ph. D. 
と鉄骨造の柱梁仕口部の変形能力について統計的性質を整理する。 最後にケーススタディを行い提案手法の効果を示すとともに, 結果 の考察から実用化に向けた課題を整理する。

\section{2. 既検査結果を反映するための定式化}

\section{1 想定した検査手順のイメージ}

本手法は, 建物の全ての梁端の一部を検査した段階で, 未検査の 梁端に破断が潜在する可能性を, 確率を用いて定量的に提供するも のである。例えば「未検査の梁端 40 箇所のうち 2 か所以上が破断

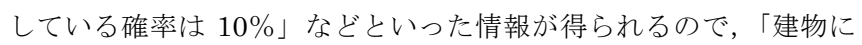
梁端破断が潜在する可能性を $5 \%$ 以下とする」などの安全水準を設 定すれば，限られた検查箇所の情報から合理的な意思決定に繋げる ことができる。また，本手法は検査箇所を随時反映するため，建物 に破断が生じていないケースでは, 安全水準に達するために事前情 報だけで決めた検查箇所すべてを検査しなくても同じ判断に至るこ とが利点である。なお, 安全水準は, 構造工学上の観点に加え, 建 物の利用状況や所有者の価值観などを反映して決まるものと考えら れるが，ここでは別の検討により与えられるものとする。

以下に，想定する検査手順を示す。

(1) 立地付近で観測した地震動記録を入力として地震応答解析を 行い, この結果と部材の変形能力から各梁端の破断確率を計算 寸る。この破断確率が, 別途定めた安全水準に達しない建物が 以下の目視確認の対象となる。

(2) 図 1 の平面骨組に模式的に例示したように, 破断確率の大きい 順に優先順位を付け，優先順位が 1 位の梁端を検査する。

(3) それまでの検査結果を用いて, 後述する方法で未検查梁端の破 断確率を更新する。

(4) 更新後の梁端の破断確率が, 安全水準を下回れば検查を終了す る。そうでなければ，更新後の破断確率が一番大きい梁端を検 査して(3)に戻る。

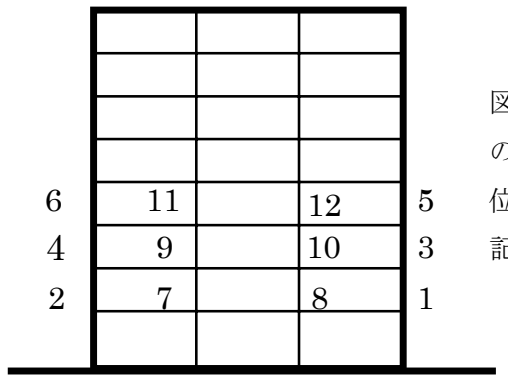

図中の番号は検查開始前 の破断確率の大きさの順 位を上位 12 か所までを 記載した例。

図 1 検査順序の模式的イメージ

\section{2 破壊確率のベイズ更新による定式化}

問題を次のように簡略化して考える。すなわち，建物が大きな摇 れを受けたあと, 破壊の可能性を考慮す心゙き部位がn䇢所あるとし, 各部位 $i(i=1, \ldots, n)$ の応答 (例えば, 梁端の最大変形角) $\Theta_{S_{i}}$ と破壞 を支配する物理量の閾值 (同じく, 破断に至るまでの変形能力) $\Theta_{\mathrm{R}_{i}}$ に 対して, それぞれの推定值 $\hat{\mathrm{S}}_{\mathrm{S}_{i}}$ と $\hat{\mathrm{B}}_{\mathrm{R}}$ はわかっているものとする。また, 各部位を個別に確認寸れば, 破壊の有無は判明するものとする。こ のとき, 未確認部位の破壞確率がある一定值以下になるようにする には, 例えば, 破壊確率の大きな部位をすべて確認してもよいが, 効率化のために既検査部位の結果を使って, 未検査部位の破壊確率
をベイズ更新することを考える。

まずは，定式化にあたり，以下の仮定をおく。

仮定 1

$\Theta_{S_{i}}$ と$\hat{\theta}_{S_{i}}$ には以下の関係がある。

$\ln \left(\frac{\Theta_{S_{i}}}{\hat{\theta}_{S_{i}}}\right)=\varepsilon_{i}$

ここで, $\varepsilon_{i}$ は正規分布 $\mathrm{N}\left(M_{\mathrm{S}}, \sigma_{\mathrm{S}}^{2}\right)$ に従う。また, $i \neq j$ うき $\varepsilon_{i}$ と $\varepsilon_{j}$ は 統計的に独立である。

仮定 2

$\varepsilon_{i}$ の標準偏差 $\sigma_{\mathrm{S}}$ は既知であるが，平均 $M_{\mathrm{S}}$ には不確定性があり，検 查前には，正規分布 $\mathrm{N}\left(\mu_{M_{S}}, \sigma_{M_{S}}^{2}\right)$ に従う。

上記の仮定は閾值についても同様に考え，例えば(1)式の $\Theta_{\mathrm{S}_{i}}$ を $\Theta_{\mathrm{R}_{i}}$ とするように，添字 $\mathrm{S}$ を R に置き換えて記述する。

この $2 つ の$ 仮定は, 応答や閾值について, 真值と推定值の比が対 数正規分布に従うこと,また,これらの各部位での比のばらつきを, 対象建物の各部位が平均的にもつ值 $M_{\mathrm{S}}$ (または $M_{\mathrm{R}}$, 以下同様) のば らつき $\sigma_{M_{\mathrm{S}}}$ と建物内での部位間でのばらつき $\sigma_{\mathrm{S}}$ に分離できることを 仮定するものである。これらの仮定の妥当性や具体的なばらつきの 大きさについては, 鋼構造梁端部を対象として, 第 3 章と第 4 章で 検討する。

次いで，部位 $i$ の状態を， $X_{i}=1$ で破壊， $X_{i}=0$ で破壊していない ことを示寸確率量 $X_{i}$ で表すものとする。また，次の仮定をおく。

\section{仮定 3}

応答 $\Theta_{\mathrm{S}_{i}}$ と閾值 $\Theta_{\mathrm{R}_{i}}$ は統計的に独立である。

仮定 1 と 3 から, $M_{\mathrm{S}}=\mu_{\mathrm{S}}$ と $M_{\mathrm{R}}=\mu_{\mathrm{R}}$ であるときに部位 $i$ が破壊して いない確率 $\mathrm{P}\left(X_{i}=0 \mid \mu_{\mathrm{S}}, \mu_{\mathrm{R}}\right)$ は(2)式で表される。

$$
\mathrm{P}\left(X_{i}=0 \mid \mu_{\mathrm{S}}, \mu_{\mathrm{R}}\right)=1-\Phi\left(-\frac{\ln \left(\hat{\theta}_{\mathrm{R}_{i}}\right)+\mu_{\mathrm{R}}-\ln \left(\hat{\theta}_{\mathrm{S}_{i}}\right)-\mu_{\mathrm{S}}}{\sqrt{\sigma_{\mathrm{S}}^{2}+\sigma_{\mathrm{R}}^{2}}}\right)
$$

ここで， $\Phi($ )は標準正規分布関数である。

応答と閾值を分離せず，安全余裕の平均として確率変数 $M=M_{\mathrm{R}}-M_{\mathrm{S}}$ を考えると, $M$ は仮定 2 と仮定 3 から正規分布 $\mathrm{N}\left(\mu_{M}, \sigma_{M}^{2}\right)$ に従う。このとき, $\mu=\mu_{M_{\mathrm{R}}}-\mu_{M_{\mathrm{S}}}, \sigma_{\mathrm{M}}^{2}=\sigma_{M_{\mathrm{R}}}^{2}+\sigma_{M_{\mathrm{S}}}^{2}$ であ る。また，(2)式の条件は次のように積分すれば外すことができる。

$$
\mathrm{P}\left(X_{i}=0\right)=\int_{+\infty}^{+\infty} \mathrm{P}\left(X_{i}=0 \mid \mu\right) \varphi\left(\frac{\mu-\mu_{M}}{\sigma_{M}}\right) \mathrm{d} \mu
$$

ここで， $\varphi($ )は標準正規確率密度関数である。また，破壊してい る確率 $\mathrm{P}\left(X_{i}=1 \mid \mu\right)$ は(4)式で計算できる。

$\mathrm{P}\left(X_{i}=1 \mid \mu\right)=1-\mathrm{P}\left(X_{i}=1 \mid \mu\right)$

さて, $(k-1)$ 番目 $(k=2, \ldots, n)$ の部位までの検査が進み, その結果 が $\left(x_{k-1}, \ldots, x_{1}\right)$ であるとき，上記と同様に考えれば， $k$ 番目の部位の 状態が $x_{k}$ である確率 $\mathrm{P}\left(X_{k}=x_{k} \mid x_{k-1}, \ldots, x_{1}\right)$ は，(5)式で表現できる。 


$$
\begin{aligned}
& \mathrm{P}\left(X_{k}=x_{k} \mid x_{k-1}, \ldots, x_{1}\right) \\
& \quad=\int_{-\infty}^{+\infty} \mathrm{P}\left(X_{k}=x_{k} \mid \mu, x_{k-1}, \ldots, x_{1}\right) \cdot f_{M \mid X_{k-1}, \ldots, X_{1}}\left(\mu \mid x_{k-1}, \ldots, x_{1}\right) \mathrm{d} \mu
\end{aligned}
$$

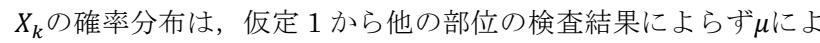
り定まるから,(5)式の被積分項のうち, 第一項は(6)式のようになる。

$$
\mathrm{P}\left(X_{k}=x_{k} \mid \mu, x_{k-1}, \ldots, x_{1}\right)=\mathrm{P}\left(X_{k}=x_{k} \mid \mu\right)
$$

第二項は， $X_{k-1}=x_{k-1}, \ldots, X_{1}=x_{1}$ を条件とした $M$ の条件付き確率 密度関数であり，仮定 2 とベイズの定理から(7)式のようになる。

$$
\begin{aligned}
& f_{M \mid X_{k-1}, \ldots, X_{1}}\left(\mu \mid x_{k-1}, \ldots, x_{1}\right) \mathrm{d} \mu \\
& \quad=\mathrm{P}\left(\mu \mid X_{k-1}=x_{k-1}, \ldots, X_{1}=x_{1}\right) \\
& \quad=\frac{\mathrm{P}\left(X_{k-1}=x_{k-1}, \ldots, X_{1}=x_{1} \mid \mu\right)}{\mathrm{P}\left(X_{k-1}=x_{k-1}, \ldots, X_{1}=x_{1}\right)} \varphi\left(\frac{\mu-\mu_{M}}{\sigma_{M}}\right) \mathrm{d} \mu
\end{aligned}
$$

(7)式第 1 項の分子は, 仮定 1 と 3 により(8)式のように単純な積 で計算できる。

$$
\mathrm{P}\left(X_{k-1}=x_{k-1}, \ldots, X_{1}=x_{1} \mid \mu\right)=\prod_{i=1}^{k-1} \mathrm{P}\left(X_{i}=x_{i} \mid \mu\right)
$$

(7)式第 1 項の分母は, (3)式と同様に（8)式で得られる条件付き確 率にMの確率密度関数を乗じて積分すれば, 条件を外すことができ る。このように, この定式化では, 各部位の予測と真值の比が, 建 物で平均的に生じている部分と部位間でばらつく部分に分離してモ デル化したことで, (6)〜(8)式に示すように多数の検查結果を条件と した(5)式の多重積分を実施することなく計算ができるという特長 を有している。

\section{3. 地震応答解析による建物内の応答のばらつきの評価 \\ 3. 1 地震応答解析におけるモデルエラーの既往研究}

地震応答解析による応答予測の誤差評価については数多の研究が なされている。例えば時刻歴解析による最大応答の予測におけるモ デルエラーの影響を扱った研究として，7階建壁付き鉄筋コンクリ 一ト造建物を対象に実際の設計で用いられる時刻歷応答解析プログ ラムで評価した結果を, 入力地震動を共通として 12 チームで比較 した事例では, レベル 2 地震動を入力としときの最大応答変形角は 平均に対して $30 \% \sim 205 \%$ の開きがあり, 誤差の最大の要因は骨格 曲線の設定の仕方によるものであった ${ }^{14)}$ 。また，米国における鋼構 造耐震設計ガイドライン ${ }^{15}$ )の技術資料 16 ) では, 多数の平面骨組の解 析結果に基づく值として, 時刻歴非線形解析から計算される最大応 答変形角の対数標準偏差として $15 \sim 25 \%$ が提示されている。しかし， これらの研究が扱ったばらつきは, 建物全体で考えたときの最大応 答の予測のばらつきであり, 第 2 章の定式化における対象建物の各 部位での平均的な誤差のばらつきと誤差の部位間のばらつきが組合 わさって生じたものである。

\section{2 建物内のばらつきの評価 \\ 3. 2. 1 モデル設定}

(1)式に示す $\varepsilon_{i}$ の統計的性質は, 対象とする建物の規模や構造計画, 入力地震動レベル，建物や入力地震動について得られている情報の 多臭などによって異なると考えられるが，このような建物内での応 答予測精度の分布のばらつきを扱った研究はみられない。そこで， 一例として, 部材の構造的性質にばらつきを与えた平面骨組の時刻 歴解析を多数実施し，定式化で述べた仮定 1，2 の確からしさを確 認するとともに $\varepsilon_{i}$ の標準偏差 $\sigma_{\mathrm{S}}$ を評価した。

対象骨組は, 鋼構造限界設計設計例 17)に記載された 9 階建事務所 建築の設計例をもとに設定した, 図 2 に示寸基礎固定の骨組である。

梁と柱の断面性能をそれぞれ表 $1 ， 2$ に示す。各部材の復元力特 性は，曲げについては，図 3 に示寸二次勾配を初期剛性の $1 / 1000$ としたバイリニア型とし，せん断については弾性変形を考慮した。

梁端が破断すると，その端部が負担していた応力がほかの部材に 再配分され, 破断が生じていないとは, その後の応答が変化するが, その影響の大きさは, 入力地震動レベル, 変形能力, 破断後の耐力 などによって異なる。一方, 地震動強さレベルの設定について後述 するように，本論文の想定する状況では，破断していないケースが 多数を占めることから, ここでは, 最低限の基本的な值を求める目 的で，破断により耐力が低下寸る影響は考慮せず評価した。

構造特性のばらつきは応答のばらつきに最も大きな影響がある降 伏耐力 $M_{y}=Z \cdot \sigma_{y}$ についてのみ考えることにして，このばらつきは 鋼材の降伏点 $\sigma_{y}$ のばらつきによりもたらされるものとした ${ }^{18)}$ 。実際 の建物では、同一断面の部材が同一ロットの鋼材から製作されてい る場合，降伏耐力には高い相関性があると考えられる。しかし、こ の相関が部材間での応答予測のばらつきに与える影響は，降伏耐力 の相関の高い部材の存在の仕方によって異なるので，ここでは基本 的な值を求める目的で独立を仮定して評価した。

鋼材の材料定数は, 縦弾性係数 $E=2.05 \times 10^{5}\left(\mathrm{~N} / \mathrm{mm}^{2}\right)$, せん断弾 性係数 $G=7.90 \times 10^{4}\left(\mathrm{~N} / \mathrm{mm}^{2}\right)$, ポアソン比 $v=0.3$ で一定とした。ま た，各階に作用する重量を表 3 に示す。

入力地震動は $\mathrm{El}$ Centro(1940)の $\mathrm{NS}$ 方向成分を最大速度 $50 \mathrm{~cm} / \mathrm{s}$ に規準化して振幅を調整した加速度波形とし，時刻歴解析は市販の 構造解析ソフトウェア $\mathrm{SNAP}^{19)}$ を用いて実行した。減衰は瞬間剛性 比例型で $3 \%$ とし，数值積分は $\beta=1 / 4$ の Newmark 法を用い，積分 時間刻みは 0.02 秒とした。

$\varepsilon_{i}$ の分布形と標準偏差 $\sigma_{S}$ は, ばらつきを含む骨組のサンプルを次 のように生成して評価した。まず，鋼材に $400 \mathrm{~N}$ 級を想定して，す

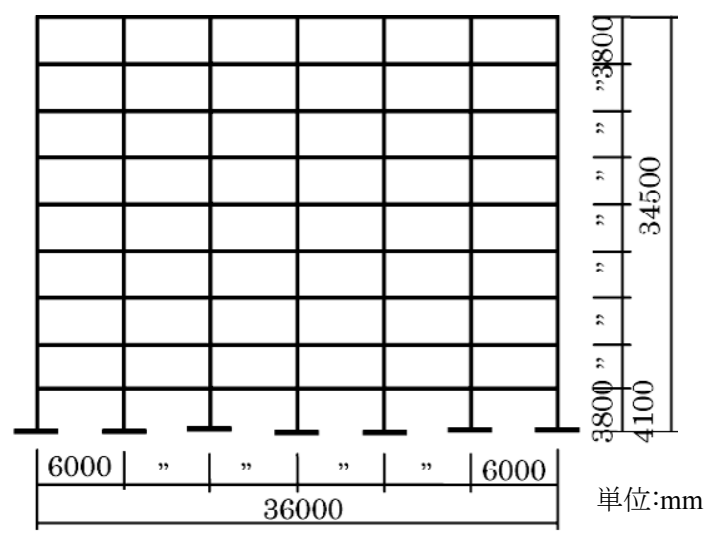

図 2 モンテカルロシミュレーションの対象骨組 
べての部材の $\sigma_{y}$ を設計基準強度の $235 \mathrm{~N} / \mathrm{mm}^{2}$ とした骨組モデルの 時刻歴解析を行い, 108 箇所の梁端の最大応答変形角の「推定值」 $\hat{\theta}_{S_{i}}$ $(i=1, \ldots, 108)$ を求める。次に, 近年の鋼材の機械的性質について整 理した文献 20)に示されている SN400B の統計量を参考に, 降伏点と して平均 $300 \mathrm{~N} / \mathrm{mm}^{2}$, 変動係数 $6 \%$ とする対数正規分布に従う独立 な擬似乱数を柱, 梁部材の数だけ発生させて, 各部材に割り当てて, 降伏耐力にばらつきを与えた骨組モデルを生成する。

この骨組モデルに対して時刻歴応答解析を行い, 各梁端の最大変 形角 $\theta_{S_{i}}$ に対して, (1) 式の実現值である $\ln \left(\theta_{S_{i}} / \widehat{\theta}_{S_{i}}\right)=\varepsilon_{i}$ を計算した ものを一組のサンプルとする。このようにばらつきを与えた骨組の サンプルを 100 組生成して, $\varepsilon_{i}$ の分布形やばらつきの大きさを検討 した。また，上記の $\mathrm{SN}$ 材を想定したものをケース 1 とし，鋼材に SS 材を想定して, 降伏点を降伏点平均 $300 \mathrm{~N} / \mathrm{mm}^{2}$, 変動係数 $12 \%$ としたケース 2 , ケース 1 で入力地震動を $75 \mathrm{~cm} / \mathrm{s}$ で規準化した加速 度波形としたケース 3 も同様に検討した。 $\sigma_{\mathrm{S}}$ は地震動強さのレベル によって変わると考えられるが, 想定している安全確認が実施され る状況は, 建物被害が疑われる一方で安全検查をするまでもなく破 壞が明らかな事態ではないことを考慮して設定したものである。表 4 に検討ケースをまとめる。

\section{2.2 評価結果}

\section{(1) 標準偏差 $\sigma_{\mathrm{S}}$ の評価}

建物内のばらつきは， $\varepsilon_{i}$ の不偏標準偏差 $\sigma_{\mathrm{S}}$ として $(9)$ 式で計算する ことができる。

$$
\begin{aligned}
& \sigma_{\mathrm{S}}=\sqrt{\frac{1}{n-1} \sum_{i=1}^{n}\left(\varepsilon_{i}-\bar{\varepsilon}\right)^{2}} \\
& \text { ここで, } \bar{\varepsilon}=\frac{1}{n} \sum_{i=1}^{n} \varepsilon_{i}
\end{aligned}
$$

表 1 梁断面一覧

\begin{tabular}{|c|c|c|c|}
\hline 階 & $\begin{array}{c}\text { 断面積 } \\
A\left(\mathrm{~mm}^{2}\right)\end{array}$ & $\begin{array}{c}\text { 断面二次 } \\
\text { モーメン } \\
I\left(\mathrm{~mm}^{4}\right)\end{array}$ & $\begin{array}{c}\text { 塑性断面係数 } \\
Z_{p}\left(\mathrm{~mm}^{3}\right)\end{array}$ \\
\hline $\mathrm{R}$ & $1.20 \times 10^{4}$ & $4.77 \times 10^{8}$ & $2.32 \times 10^{6}$ \\
\hline 9 & $1.20 \times 10^{4}$ & $4.77 \times 10^{8}$ & $2.32 \times 10^{6}$ \\
\hline 8 & $1.20 \times 10^{4}$ & $4.77 \times 10^{8}$ & $2.32 \times 10^{6}$ \\
\hline 7 & $1.31 \times 10^{4}$ & $5.38 \times 10^{8}$ & $2.61 \times 10^{6}$ \\
\hline 6 & $1.31 \times 10^{4}$ & $5.38 \times 10^{8}$ & $2.61 \times 10^{6}$ \\
\hline 5 & $1.31 \times 10^{4}$ & $5.38 \times 10^{8}$ & $2.61 \times 10^{6}$ \\
\hline 4 & $1.43 \times 10^{4}$ & $5.98 \times 10^{8}$ & $2.89 \times 10^{6}$ \\
\hline 3 & $1.43 \times 10^{4}$ & $5.98 \times 10^{8}$ & $2.89 \times 10^{6}$ \\
\hline 2 & $1.43 \times 10^{4}$ & $5.98 \times 10^{8}$ & $2.89 \times 10^{6}$ \\
\hline & & & \\
\hline
\end{tabular}

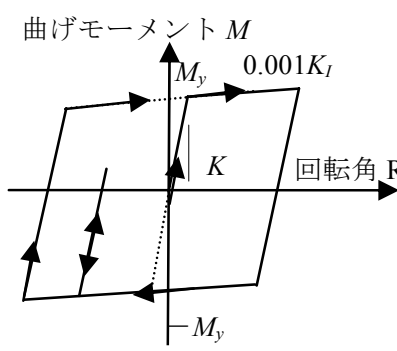

図 3 部材の曲げ復元力特性
表 4 検討ケース一覧

\begin{tabular}{|c|c|c|}
\hline ケース & $\begin{array}{c}\text { 降伏点の } \\
\text { 変動係数 }\end{array}$ & $\begin{array}{c}\text { 入力地震動の } \\
\text { 規準化速度 }\end{array}$ \\
\hline 1 & $6 \%$ & $50 \mathrm{~cm} / \mathrm{s}$ \\
\hline 2 & $12 \%$ & $50 \mathrm{~cm} / \mathrm{s}$ \\
\hline 3 & $6 \%$ & $75 \mathrm{~cm} / \mathrm{s}$ \\
\hline
\end{tabular}

3 ケース, 各 100 サンプルに対して $\sigma_{\mathrm{S}}$ を計算し，ケース別に平均 と不偏標準偏差を計算したところ, ケース 1 では平均 0.117 , 不偏 標準偏差 0.011 , ケース 2 では平均 0.127 , 不偏標準偏差 0.016 , ケ 一ス 3 では平均 0.136 , 不偏標準偏差 0.018 となった。部材耐力の ばらつきが大きい場合や平均的に大きな塑性変形を被る場合には, ややばらつきが大きくなる傾向がみられるが，ここで検討した範囲 では先に述べた既往の研究で示されている最大応答のばらつきより も相当小さな值が得られた。これらの結果を表 5 にまとめて示す。 表 5 には, 後述する正規性の確認の結果も記載している。また, 各 ケースにおける最大変形を生じた梁端の塑性率の平均は，ケース 1 とケース 2 が 2.29 , ケース 3 が 3.06 であった。

なお，ここで求めた值には，先述の破断後の応答変化の影響のほ か，建物の 3 次元的な挙動の影響も含まれていない。その他，ここ で示すモデルでは考慮していない要因が，建物内の忘答分布に与え る影響が大きいと考えられる建物を対象とする場合, 適切なモデで 改めてシミュレーションを行うことが望ましいが，次善にはシミュ レーションで考虑しきれない要因の影響として, 上記の值よりも幾 らか大きめのばらつきを設定することも考えられる。

\section{（2）正規性の確認}

次に定式化において仮定した $\varepsilon_{i}$ の正規性を確認する。ここでは, 検定統計量 $J B$ が漸近的に自由度 2 のカイ 2 乗分布に従うことを利用 した Jarque-Bera 検定 ${ }^{21)}$ にり正規性を検定した。

$$
J B=\frac{n}{6}\left\{S^{2}+\frac{1}{4}(K-3)^{2}\right\}
$$

上式において， $S, K$ はそれぞれ次式で定義される標本歪度 $S$ (skewness) と標本尖度 $K$ (kurtosis) である。正規分布では $S=0$, $K=3$ であり， $\varepsilon_{i}$ が正規分布に従うとすればJ $B$ は 0 に近い值となる。

表 2 柱断面一覧

\begin{tabular}{|c|c|c|c|}
\hline 階 & $\begin{array}{c}\text { 断面積 } \\
A\left(\mathrm{~mm}^{2}\right)\end{array}$ & $\begin{array}{c}\text { 断面二次 } \\
\text { モーメン } \\
I\left(\mathrm{~mm}^{4}\right)\end{array}$ & $\begin{array}{c}\text { 断面係数 } \\
Z\left(\mathrm{~mm}^{3}\right)\end{array}$ \\
\hline $\mathrm{R}$ & $2.90 \times 10^{4}$ & $7.02 \times 10^{8}$ & $4.14 \times 10^{6}$ \\
\hline 9 & $2.90 \times 10^{4}$ & $7.02 \times 10^{8}$ & $4.14 \times 10^{6}$ \\
\hline 8 & $2.90 \times 10^{4}$ & $7.02 \times 10^{8}$ & $4.14 \times 10^{6}$ \\
\hline 7 & $3.33 \times 10^{4}$ & $7.95 \times 10^{8}$ & $4.72 \times 10^{6}$ \\
\hline 6 & $3.33 \times 10^{4}$ & $7.95 \times 10^{8}$ & $4.72 \times 10^{6}$ \\
\hline 5 & $3.33 \times 10^{4}$ & $7.95 \times 10^{8}$ & $4.72 \times 10^{6}$ \\
\hline 4 & $3.75 \times 10^{4}$ & $8.83 \times 10^{8}$ & $5.28 \times 10^{6}$ \\
\hline 3 & $3.75 \times 10^{4}$ & $8.83 \times 10^{8}$ & $5.28 \times 10^{6}$ \\
\hline 2 & $4.17 \times 10^{4}$ & $9.66 \times 10^{8}$ & $5.82 \times 10^{6}$ \\
\hline
\end{tabular}

表 3 各階重量

\begin{tabular}{|c|c|}
\hline 階 & $\begin{array}{c}\text { 重量 } \\
W_{i}(\mathrm{kN})\end{array}$ \\
\hline 8 & 2085 \\
\hline 9 & 1478 \\
\hline 8 & 1478 \\
\hline 7 & 1478 \\
\hline 6 & 1478 \\
\hline 5 & 1478 \\
\hline 4 & 1478 \\
\hline 3 & 1478 \\
\hline 2 & 1498 \\
\hline
\end{tabular}

表 5 モンテカルロシミュレーションによる $\sigma_{S}$ の統計值と正規性 を示す統計量

\begin{tabular}{|c|c|c|c|c|}
\hline \multirow{2}{*}{ ケース } & \multicolumn{2}{|c|}{$\sigma_{\mathrm{S}}$} & \multicolumn{2}{c|}{ JB検定統計量 } \\
\cline { 2 - 5 } & 平均 & 標準偏差 & 平均 & 標準偏差 \\
\hline 1 & 0.117 & 0.011 & 0.388 & 0.196 \\
\hline 2 & 0.127 & 0.016 & 0.257 & 0.152 \\
\hline 3 & 0.136 & 0.018 & 0.319 & 0.104 \\
\hline
\end{tabular}




$$
\begin{aligned}
& S=\frac{1}{n} \frac{\sum_{i=1}^{n}\left(\varepsilon_{i}-\bar{\varepsilon}\right)^{3}}{\hat{\sigma}_{\varepsilon}{ }^{3}} \\
& K=\frac{1}{n} \frac{\sum_{i=1}^{n}\left(\varepsilon_{i}-\bar{\varepsilon}\right)^{4}}{\hat{\sigma}_{\varepsilon}{ }^{4}}
\end{aligned}
$$

ここで, $\hat{\sigma}_{\varepsilon}$ は各サンプルにおいて計算される標本標準偏差であり， (1)式の不偏標準偏差とは次式の関係がある。

$$
\hat{\sigma}_{\varepsilon}=\sigma_{\mathrm{S}} \sqrt{\frac{n-1}{n}}
$$

ケース 1 では 100 ケースのJBの平均が 0.388 , 標本標準偏差が 0.196 であった。また, 同じくケース 2 では平均 0.257 , 標本標準 偏差 0.152 , ケース 3 では, 平均 0.319 , 標本標準偏差 0.104 とな った。

帰無仮説を $\mathrm{H}_{0}$ 「標本が正規分布に従う」として有意水準 $5 \%$ で検 定する場合，JBが 5.991 以上のときに帰無仮説が棄却されるが，い ずれのケースでもそのようなサンプルはなく，正規分布に従わない とはいえないことが確認できた。図 4 に，一例としてケース 1 にお ける, あるサンプルの $\varepsilon_{i}$ の累積確率分布を正規分布のそれと比較し て示す。この例の歪度は -0.42 , 尖度は 2.58 である。

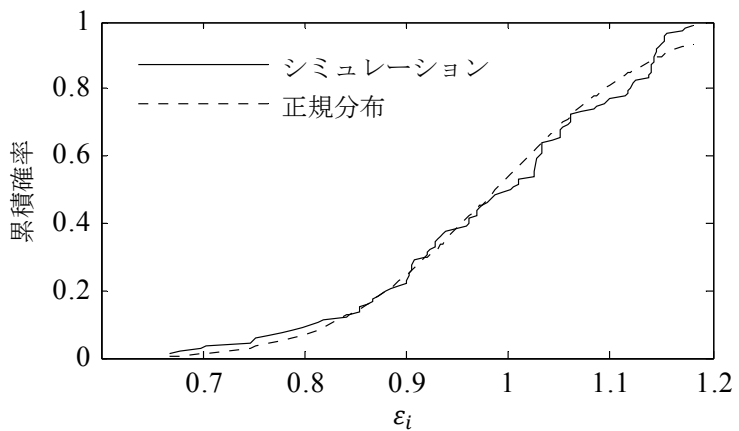

図 4 梁端の最大回転角の予測值との比の対数の累積確率分布 の一例

\section{4. 建物内における鉄骨造柱梁仕口部の変形性能のばらつきの評価 4. 1 仕口部の変形性能関する既往の統計的研究}

鉄骨造仕口部の塑性変形能力に関する統計的研究としては, 部材

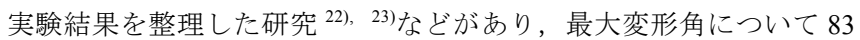
体の実大実験の実験データ ${ }^{24)}$ を整理したところ対数標準偏差は 33 〜37\%となった ${ }^{23)}$ 。しかし，これらの部材に関する既往研究はいず れも断面や載荷パターンが異なる実験データを集めて評価したもの であり, 本論文で定義した, 対象建物がもつ平均的な誤差のばらつ き $\sigma_{M_{\mathrm{R}}}$ と建物内での部位間のばらつき $\sigma_{R}$ をわわたものに対応する。 $\sigma_{\mathrm{R}}$ を評価するには，同一の断面，同一の載荷パターンで得られた 実験データのばらつきを調べる必要がある。このような条件でばら つきを評価すれば，上記に比べて小さい值となると予想されるが， 部材を対象に条件を統一して多数の実験を実施して最大変形角のば らつきを評価した例はみられない。一方, 累積塑性変形については,
同一条件で部材実験を 2 回ずつ実施した研究 ${ }^{25)}$ があるので，この 実験デー夕を対象に $\sigma_{\mathrm{R}}$ を評価して代用することとした。

\section{2 同一条件の実験データにおける変形性能のばらつき}

ここで用いたデータは角型鋼管柱と $\mathrm{H}$ 型鋼梁のノンスカラップ工 法による接合部の実大構造実験によるものであり，柱パネルの板厚 を変えた 2 種類の試験体に一定振幅で交番載荷したときの最大耐力 や終局（亀裂進展）までの累積塑性変形倍率である。表 6 に，文献 25 に示されている 8 組 16 体分のデータを引用した。表 6 の試験名 称に記載された 3 文字のラテン文字が試験体の種類を表し, ハイフ ンのあとの数字が振幅（梁端が全塑性モーメントに達するときの梁 の回転角の弾性成分を基準とする塑性率）を表す。また，サイクル 数 $N$, 累積塑性変形倍率 $\eta$ は, 添字 $\mathrm{U}, \mathrm{F}$ により, それぞれが終局状態 (耐力が最大耐力の $90 \%$ を下回った時点もしくはフランジ溶接部 が最終破断した状態），最終破断状態のものであることを表す。 上記の実験データに対して, 仕口部の変形能力が対数正規分布に従 うと仮定し，さらに実験条件によって対数平均は異なるが対数標準 偏差は共通の值〉をもつと仮定する。このため, 第 2 章で述べた仮 定に比べると, 部材断面や載荷条件を変えることによる対数標準偏 差のばらつきの分だけ $\sigma_{\mathrm{R}}$ をきめに見積もることになる。また，表 6 を詳しくみると振幅の小さい試験ほど試験体 A と B で結果に差が ある傾向がみられるので, 最大変形角にあてはめるとばらつきを過 大評価するものと予想されるが，この条件を課すことで次のように ろを推定することができる。

実験条件 $i(i=1, \ldots, 8)$ の実験から得られた変形能力を $\xi_{i, \mathrm{~A}}, \xi_{i, \mathrm{~B}}$ と寸 ると, $r_{i}=\xi_{i, \mathrm{~A}} / \xi_{i \mathrm{~B}}$ は対数正規分布に従い, 実験条件を共通とするの で $r_{i}$ の期待值は 1 である。また， $r_{i}$ の対数をとった $x_{i}=\ln \left(r_{i}\right)$ は期待 值 0 の正規分布に従う。

さて, 期待值 $\mu_{x}$ が既知の正規分布について, $n$ 個のサンプルが得ら れたとき，その分散 $\sigma_{x}^{2}$ 無情報事前分布を用いてベイズ推定した場 合の事後分布は, 自由度 $n$, 尺度母数 $T^{2}$ の逆カイ 2 乗分布 $\mathrm{X}^{-2}\left(n, T^{2}\right)$ と なることが知られており，その点推定值として事後分布の平均 $T^{2} /(n-2)$, あるいは最頻值 $T^{2} /(n+2)$ などを用いることができる ${ }^{26)}$

表 6 同一条件による塑性変形能力の実験データ 25)より引用

\begin{tabular}{|c|c|c|c|c|}
\hline \multirow{2}{*}{ 試験名称 } & \multicolumn{2}{|c|}{ サイクル数 } & \multicolumn{2}{c|}{ 累積塑性変形倍率 } \\
\cline { 2 - 5 } & $N_{\mathrm{U}}$ & $N_{\mathrm{F}}$ & $\eta_{\mathrm{U}}$ & $\eta_{\mathrm{F}}$ \\
\hline NSS-1.2A & 235 & 274 & 207 & 248 \\
\hline NSS-1.2B & 198 & 225 & 158 & 186 \\
\hline NSS-2.0A & 61 & 63 & 186 & 196 \\
\hline NSS-2.0B & 52 & 55 & 153 & 163 \\
\hline NSS-3.0A & 25 & 25 & 155 & 155 \\
\hline NSS-3.0B & 20 & 20 & 123 & 123 \\
\hline NSS-4.0A & 13 & 13 & 127 & 127 \\
\hline NSS-4.0B & 14 & 14 & 126 & 126 \\
\hline NSW-1.2A & 205 & 220 & 171 & 185 \\
\hline NSW-1.2B & 193 & 280 & 164 & 301 \\
\hline NSW-2.0A & 37 & 38 & 108 & 111 \\
\hline NSW-2.0B & 26 & 28 & 76 & 81 \\
\hline NSW-3.0A & 14 & 15 & 88 & 88 \\
\hline NSW-3.0B & 17 & 17 & 98 & 98 \\
\hline NSW-4.0A & 7 & 7 & 63 & 63 \\
\hline NSW-4.0B & 6 & 6 & 52 & 52 \\
\hline
\end{tabular}


ここで， $T^{2}$ は以下の(15)式で計算される值である。

$$
T^{2}=\sum_{i=1}^{n}\left(x_{i}-\mu_{x}\right)^{2}
$$

表 6 に掲載した值のうち, 終局に至る累積塑性変形倍率 $\eta_{\mathrm{U}}$ につ て, (15)式の $T^{2}$ を計算すると 0.445 であり, 同じく最終破断に至る累 積塑性変形倍率 $\eta_{F}$ については 0.561 となった。

従って, $x_{i}$ の分散 $\sigma_{x}{ }^{2}$ を事後分布の平均で推定すれば, 終局に対し て 0.074 , 最終破断に対して 0.093 となる。また, $x_{i}=\ln \left(r_{i}\right)=$ $\ln \left(\eta_{i, \mathrm{~A}}\right)-\ln \left(\eta_{i, \mathrm{~B}}\right)$ であるから, その分散については $\sigma_{x}^{2}=\zeta^{2}+\zeta^{2}$ であ る。これをろについて解くと(16)式になる。この式に上記の $\sigma_{x}{ }^{2}$ の值 を代入すれば, 累積塑性変形倍率の対数標準偏差孔は, 終局に対して 0.19 , 最終破断に対して 0.22 を得る。

$$
\zeta=\sqrt{\frac{\sigma_{x}^{2}}{2}}
$$

\section{9 層骨組を対象とした事例計算}

\section{1 モンテカルロシミュレーションとの比較}

提案手法により未検查部位の破断の可能性が定量的に評価できる ことを確認するために, 第 3 章で建物内の応答評価のばらつきを評 価する際に用いた 9 層骨組を対象に, 次の手順でサンプルを生成し たモンテカルロシミュレーションを行い, 安全確認の各段階で計算 される未検査部位の破断確率と比較した。

まず，第 3 章で応答のばらつきを評価した際のケース 3 , すなわ ち, 鋼材の降伏点を平均 $300 \mathrm{kN} / \mathrm{m}^{2}$, 変動係数 $6 \%$ の対数正規分布に 従う独立な擬似乱数を用いて生成した骨組 1000 個に, 最大速度を $75 \mathrm{~cm} / \mathrm{s}$ に規準化した El Centro (1940) NS を入力地震動とした時刻歴 解析により求めた最大応答変形角を応答のサンプルとした。

また, 変形能力は, 平均 $1 / 30 \mathrm{rad}$, 標準偏差 $\sigma_{M_{\mathrm{R}}}=\sqrt{0.4^{2}-0.2^{2}}=$ 0.35 の正規分布に従う擬似乱数により平均変形能力のサンプルを 1000 個生成し, 次いで, これらのサンプルを平均とし, 対数標準偏 差 $\sigma_{\mathrm{S}}=0.20$ の対数正規分布に従う擬似乱数をそれぞれ 108 個生成し て, 変形能力のサンプルとした。

応答予測 $\widehat{\theta}_{\mathrm{S}_{i}}$ は, 鋼材の降伏点に設計基準強度である $235 \mathrm{~N} / \mathrm{mm}^{2}$ を 用いた骨組の時刻歴解析結果とし，このときの最大変形角を降順に 並べると図 5 のようになった。また, 図 6 に骨組上での順位を示し た。このケースでは応答が骨組の中心線に対して左右対称になるの で, 同図は簡便のため骨組左側での順位を記載しているが, 左右対 称となる位置を双方確認したあと次の位置を確認する, つまり最初 は第 5 層床の両端部が対象であり, 次にその下層の両端が対象とな ることを意味している。この順で検査する（左右の順序は任意）こ とにして, 各骨組サンプルについて, 応答と変形能力をこの順に並 べ替えたときに, $k$ 番目以後 $(k=1, \ldots, 108)$ のいずれの梁端でも応 答が変形能力を超えていないかを確認し, 超えていない骨組の比率 を求めれば $(k-1)$ 番目の梁端までの検查が終了したときに未検査 の梁端に破断がない確率のシミュレーション結果となる。

一方, 理論值 $\mathrm{P}\left(X_{n}=0, X_{n-1}=0, \ldots, X_{k}=0 \mid x_{k-1}, \ldots, x_{1}\right)$ は, 第 2 章 に示した各梁端の破断確率と同様の考え方により導かれる (17)式
で計算できる。

$$
\begin{aligned}
\mathrm{P}\left(X_{n}\right. & \left.=0, X_{n-1}=0, \ldots, X_{k}=0 \mid x_{k-1}, \ldots, x_{1}\right) \\
& =\int_{-\infty}^{+\infty} \prod_{\mathrm{l}=\mathrm{k}}^{\mathrm{n}} \mathrm{P}\left(X_{l}=0 \mid \mu\right) \cdot f_{M \mid X_{k-1}, \ldots, X_{1}}\left(\mu \mid x_{k-1}, \ldots, x_{1}\right) \mathrm{d} \mu
\end{aligned}
$$

図 7 には, 未検查の梁端に破断がない確率を (17)式による理論 值とシミュレーション（数值実験）で比較した。同図は, 各サンプ ルについて理論值が横軸の值になったときの検査対象とした梁端を 選び，残りのいずれの梁端でも応答が変形能力を超えていないサン プルの比率を求めて縦軸の值としたものである。

線分は理論值=数值実験となるときのものであり, 理論值が未検査 部位に破断がない確率を過大評価（工学的に危険側）すれば線分よ

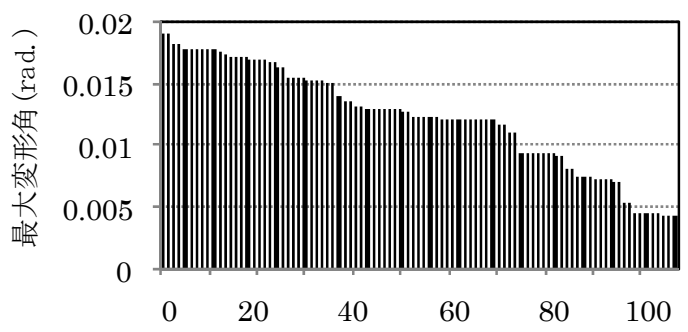

梁端の最大変形角の順位

図 5 絶対值が大きい順に並べた梁端の最大変形角の予測值

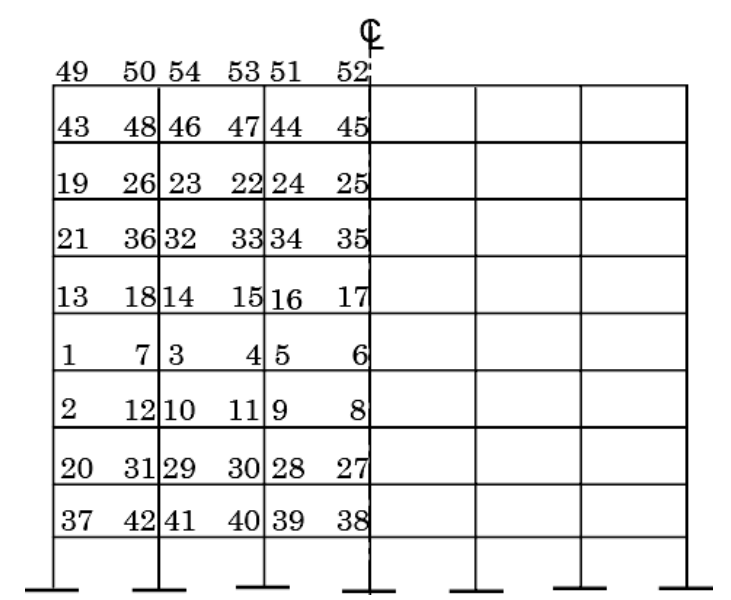

図 6 最大変形角の絶対值が大きい順に並べた梁端の順位

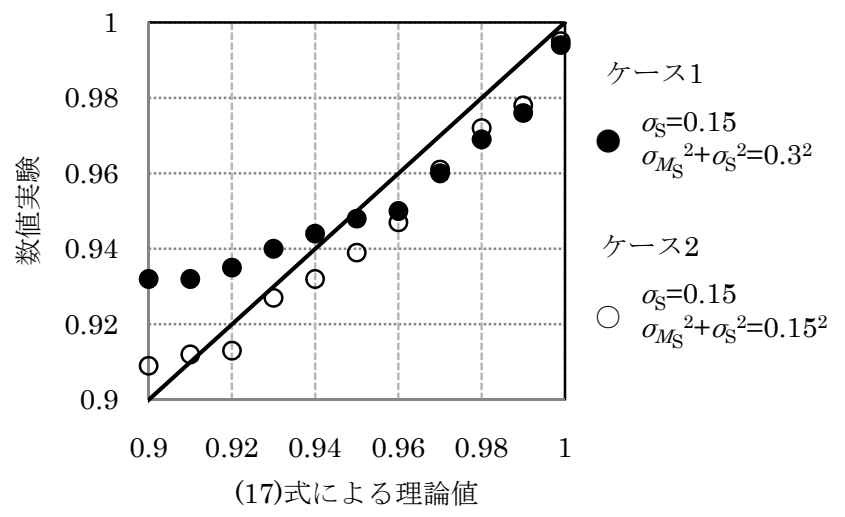

図 7 提案手法により求められる未検査の梁端に破断がない確率 とモンテカルロシミュレーションの比較 
りも下側に, 過小評価（工学的に安全側）に評価すれば上側に図示 される。

図 7 には, ベイズ更新に用いる応答の予測值のばらつきを変えた 2 ケースのシミュレーション結果が記載されている。で示すケー ス 1 は第 3 章で述べた一般的に考えられるケースに対応し, 応答の 予測との比の対数に対して, 平均の平均を 0 , 平均の標準偏差を $\sigma_{M_{\mathrm{S}}}=\sqrt{0.3^{2}-0.15^{2}}=0.26$ とし， $\sigma_{\mathrm{S}}=0.15$ としたケースである。一 方, ○のケース 2 はシミュレーションにあわせて平均のばらつきは ないものとして $\sigma_{M_{\mathrm{S}}}=0, \sigma_{\mathrm{S}}=0.15$ としたケースである。また, 変形 能力のばらつきは，いずれのケースもサンプルを生成したものと同 様に平均 $1 / 30 \mathrm{rad}$, 平均の標準偏差 $\sigma_{M_{\mathrm{R}}}=0.35$, 対数標準偏差 $\sigma_{\mathrm{S}}=0.20$ とした。

図 7 に示寸通り理論值はシミュレーションと概数整合しており, 提案手法を用いることで検查前の情報から必要とされる検查個所を す心゙て確認しなくても, 破断が潜在する確率を予め設定した值以下 にできることを示している。

また, 図 7 を詳細に見ると, 破断がない確率が高い範囲ではやや 危険側の評価となり，逆に低い範囲では安全側の評価となる傾向が ある。提案手法では一部の部位の検査結果だけで更新された安全余 裕の分布（以下，更新中の分布）に基づいて安全確認の終了判断を するため, 建物内のばらつきだけが存在する分布（最終的な分布） との間にそれぞれ破断確率を過大，過小に評価する 2 種類の差があ るからである。これらの差を図 8 と図 9 に模式的に示す。

図 8 は, 平均のばらつきが含まれる分, 更新中の分布は最終的な 分布よりばらつきが大きく, 破断確率を過大評価する要因となるこ とを示している。一般的には，検査終了と判断するときの破断がな い確率が低いほど, 少ない検査結果に基づき終了判断がなされるた め, 更新中の分布のばらつきが大きい。ケース 1 がケース 2 に比べ て理論值と数值実験で差がある理由は, ケース 1 の方が事前分布に おいて応答分布の平均のばらつきを大きく設定した分，この影響が 大きく, 事前分布のばらつきを精度よく推定することが検查効率を 上げるのに重要であることを意味している。

一方, 図 9 は, 破断確率を過小評価する要因を示す。事前に想定 する安全余裕の平均の平均が最終的な分布の平均よりも大きい場合, すなわち予測応答が平均的に小さめに予測したか，変形能力を大き めに予測したかのいずれか，もしくは両方の場合に生ずるもので, 平均が十分小さくなる前に閾值に到達して安全確認を終了するため 生ずるものである。逆に事前に想定した安全余裕の平均が小さい場 合には閾值に達しないので,このような誤差は発生しない。つまり, 安全余裕の事前分布の平均をやや小さめに設定すれば破断確率を過 小評価することは避けられる。

\section{2 今後の課題}

本論文は, 震災後の建物の安全を効率的に確認する検査戦略を構 築する先鞭として，基本的な考え方を定式化したものである。実用 化に向けた今後の主な課題として以下の 3 点が挙げられる。

(1) 実施上の制約を勘案した標準的な検查方針の立案

(2) 応答予測の簡略化と予測方法に応じたばらつきの定量化

(3) 変形能力のばらつきの精度向上

本論文では，順次，検査箇所を増や寸想定で定式化しているが， 淮備等の都合を考えると破断の有無を確認しながら検査数を変える
方法が採られるとは考えにくい。実際には，破断が見つからない前 提で求められる安全レベルを確保するために検查すべき箇所を定め た実施計画を策定し，検查を実施した結果，もし破断が見つかった 場合には改めて対策を検討寸るものと考えられる。

例えば 5.1 節で示したケースでは，いずれの検査でも破断が見つ からない場合の検查箇所数と未検查の梁端に破断がない確率の関係 は，図 10 に示すように第 5 層の梁端（計 12 箇所）を検查すれば約 $90 \%$ 以の確率で破断がないことがいえる。そこで，まずは最も破 断の可能性が高い層を抽出して検査するなどの戦略を設定して事例 解析を行うことで検査戦略の標準例を立案できる。また，破断が見 つかった場合には, 安全確認とは別に破断を探索する観点で検查順 序を決める方法を検討しておけばよい。

また、本論では検查の要否を判断するための安全水準は外的に与 えられるものとした。安全水準の設定は検査方針立案の前提である

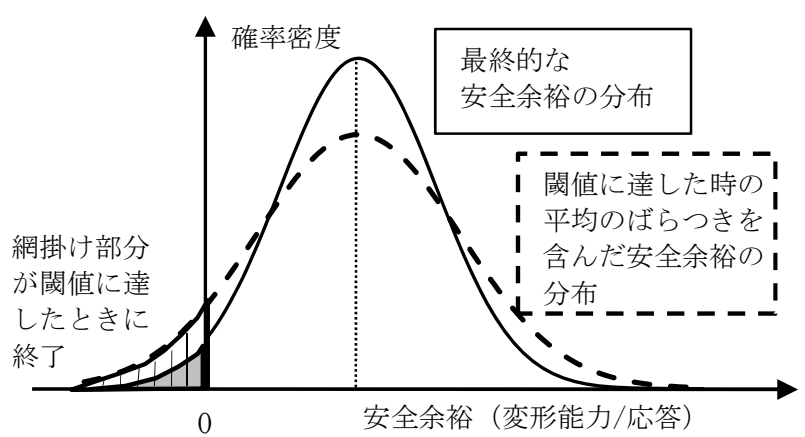

図 8 破断確率を過大評価する原因を示寸模式図

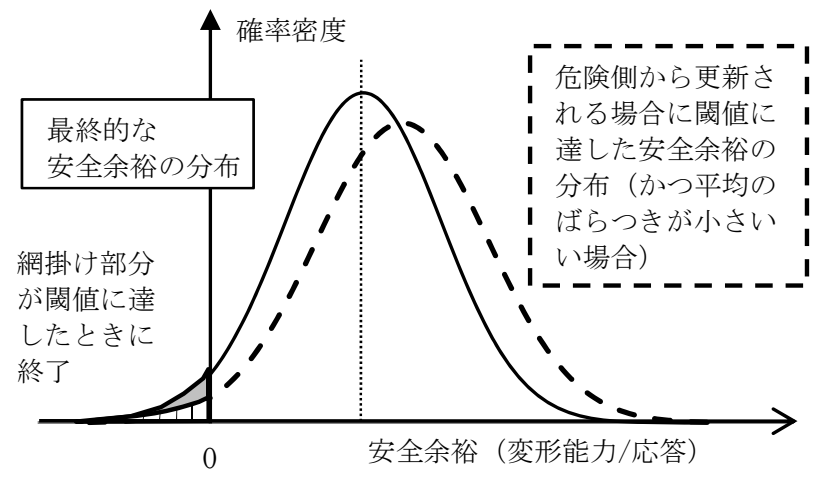

図 9 破断確率を過少評価する原因を示す模式図

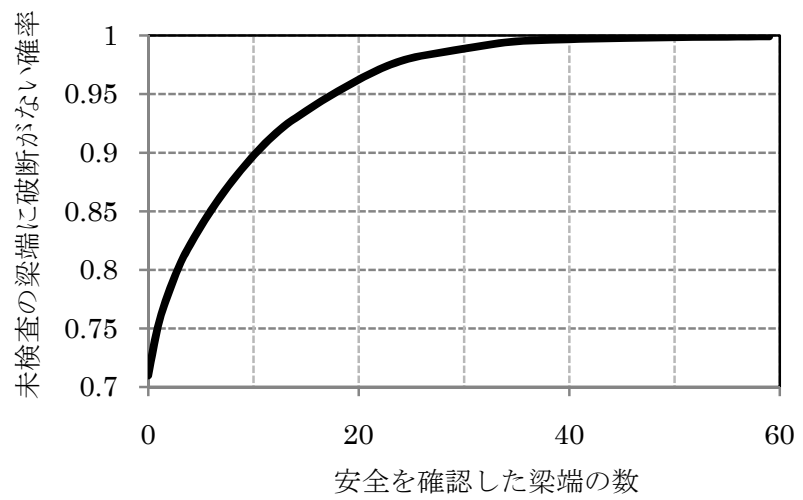

図 109 層骨組の事例解析における安全確認済みの梁端の 数と未検查の梁端に破断がない確率の関係 
が, 確率情報に基づく意思決定には多くの考え方があり, 実用化に 向けた検討課題のひとつである。

2 番目の課題である応答予測の簡略化は, 必ずしも精度のよい解 析結果が利用できるとは限らないことに対応寸るものである。例え ば設計情報を応答予測に用いることも考えられる。その際, 部材間 の応答予測のばらつきの大きさが安全確認の効率 ${ }^{27}$ や精度に影響す るが，典型的な状況をいくつか想定してそれぞれ第 3 章に示したよ うな数值実験を行うことでばらつきを評価できる。あわせて, ここ では考慮しなかった破断による応答の変化や入力地震動によっても

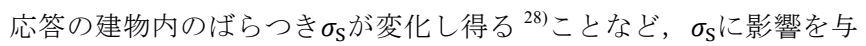
える要因を整理し，その影響の大きさを評価しておく。

3 番目の課題は実験データの蓄積が不可欠であり, 上の 2 つのほ ぞ解決への道筋は平坦ではない。本論文では, 限定的なものではあ るが, 部材の変形能力のばらつきを既往実験のデータから統計的に 推定した。一方，まったく同一の試験体で実施された試験ではほと んど変形能力が一致したという報告 ${ }^{29)}$ もされており, 今後も継続 的に知見を積み重䄈ることが望まれる。

\section{6.おわりに}

鋼構造梁端の破断が潜在する可能性を想定して, 効率的に建物の 安全を確認するために一部の部材の目視確認結果を利用して, 未検 查の部材の破壊確率をべイズ更新する手法を定式化した。提案手法 は, 各部位の応答と変形能力の予測誤差を建物全体としての平均的 な誤差と部位間のばらつきに分離してモデル化し，平均的な誤差だ けをべイズ更新するもので，多数の部位の検査結果を条件とする条 件付きの破断確率を少ない計算量で計算できる。

また， 9 層の平面骨組を対象に時刻歴応答解析にモンテカルロシ ミュレーションを行い最大応答分布の建物内でのばらつきを検討し たところ, 応答のばらつきの要因として降伏点のばらつきを考えた ケースでは対数標準偏差が 12〜 14\%と得られた。変形能力について 鉄骨造の柱梁仕口部の既往実験のデータを利用して同一条件におけ る塑性変形能力のばらつきを推定したところ, 累積塑性変形倍率の 対数標準偏差は終局に対して $19 \%$, 最終破断に対して $22 \%$ となった。 事例計算として，提案手法により得られる検査の各段階における 破断が潜在している確率をモンテカルロシミュレーションと比較し, 良好な精度を確保できることを確認した。あわせて誤差が生ずる要 因と実用化に向けた課題を(1)実施上の制約を勘案した標準的な検査 方針の立案，(2)応答予測の簡略化と予測方法に応じたばらつきの定 量化，(3)変形能力のばらつきの精度向上という観点から考察した。 今後は, 標準的な検查方針の立案と応答予測の簡略化やばらつき の精度向上に取り組む予定である。

\section{参考文献}

1) 日本建築学会構造委員会長周期建物地震対策対応ワーキンググループ: 長 周期地震動対策に関する公開研究集会資料, 2010.3.

2) 財団法人日本建築防災協会 : 震災建築物の被災度区分判定基準および復旧 技術指針, 2002.8.

3) 斉藤知生 : モード解析型多入力多出力 ARX モデルを用いた高層建物のシ ステム同定，日本建築学会構造系論文集，第 508 号, pp.47-54, 1998.6.

4）金澤健司：常時微動振動計測に基づく構造物の損傷探査法(その 4) 長期連 続振動モニタリングによる振動特性の経時変化による分析, 電力中央研究 所報告, 2005.5.
5) 中村充, 竹脇出, 安井譲, 上谷宏二: 限定された地震観測記録を用いた建築 物の剛性と減衰の同時同定，日本建築学会構造系論文集，第 528 号, pp.75-82, 2000.2.

6) 飛田潤, 福和 伸夫, 西澤崇雄: 光ファイバーセンサーによる鋼構 造試験体の静的 - 動的柱軸変形の計測, 構造工学論文集, Vol.55B, pp.577-582, 2009.3.

7) 濱本卓司：性能評価のためのヘルスモニタリング，建築防災，No.318， pp.9-15, 2004.7.

8) Daniel Straub, Michael Havbro Faber: Risk based inspection planning for structural systems, Structural safety, Vol.30, pp.335-355, 2005.

9) 森保宏: 而力劣化する構造物の信頼性評価法, 日本建築学会構造系論文集, 第 465 号, pp.37-44, 1997.11 .

10) Andre D. Orcesi, Dan M. Frangpool: Optimization of bridge maintenance strategies based on structural health monitoring information, Structural Safety, Vol.33, pp.26-41, 2011.

11) Daniel Straub, Armen Der Kiureghian: Improved seismic fragility modeling from empirical data, Structural safety, Vol.30, pp.11-21, 2008.

12) Fatemeh Jalayer, Ludovica Elefante, Iunio Iervolino, Gaetano Manfredi: Knowledge-Based Performance Assessment of Existing RC Buildings, Journal of Earthquake Engineering, Vol.15, pp.362-389, 2011.

13) Qindan Huan, Paolo Gardoni, Stefan Hulebaus: A probabilistic damage detection approach using vibration-based nondestructive testing, Structural safety, Vol.38, pp.11-21, 2012.

14）辻幸二, 山口圭介, 深野慶, 窪田敏行:耐震性能評価用の各種解析プログラ ムによる RC 造建物の地震応答解析結果の比較, 日本建築学会構造系論文 集，第 550 号, pp.119-126, 2001.12.

15) Federal Emergency Management Agency:Recommended Seismic Design Criteria for New Steel Moment-Frame Buildings, FEMA-350, 2000.

16) Federal Emergency Management Agency: State of the Art Report on Performance Prediction and Evaluation of Steel Moment-Frame Buildings Appendix B, FEMA-355F, 2000.

17) 日本建築学会 : 鋼構造限界設計設計例, 日本建築学会, 2002.

18）中島正愛，吉良圭史，辻文三 : 構造物に要求される消費エネルギーに対 して構造各部材に要求される塑性変形量とそのばらつきの評価法, 日本建 築学会構造系論文集, 第 494 号, pp.99-105, 1997.4.

19) 株式会社構造システム:SNAP Ver. 6 テクニカルマニュアル, 2012.

20) 井戸田 秀樹, 鏡味 亮, 金子 翔太:素材特性の不確定な変動を考慮した $\mathrm{H}$ 形鋼梁部材の耐力と変形性能, 日本建築学会構造系論文集, 第 681 号, pp.1791-1800, 2012.11.

21) Carlos M. Jarque, Anil K. Bera: A test for normality of observations and regression residuals, International Statistical Review, Vol. 55, No. 2, pp. 163-172, 1987.8 .

22）野田隆博, 井戸田秀樹, 小野徹郎, 実験データに基づく鋼構造柱梁溶接接 合部の変形性能に関する統計量調査, 日本建築学会大会学術講演梗概集, 構造III, pp.965-966, 2003. 9 .

23) 日下彰宏, 加登美喜子, 岡崎太一郎:米国信頼性耐震設計の概要と梁の塑 性変形性能の確率的評価の日米比較, 日本鋼構造協会, 鋼構造論文集, 第 12 巻第 45 号, pp.87-100, 2005. 3 .

24) 井上一朗，甲津功夫，吹田啓一郎，多田元英，立山英二，田中剛，中島正 愛, 丸岡義臣, 南二三吉, 森田耕次: 通しダイアフラム形式で角形鋼管柱に 接合される $\mathrm{H}$ 型鋼梁の塑性変形能力に関する実大実験その 1 その 5 , 鋼構 造論文集, 第 4 巻第 16 号, pp.27-104, 1997. 12.

25) 吹田啓一郎, 田中剛, 佐藤篤司, 真鍋義貴, 津嘉田敬章, 蘇鐘ギョク:梁端 接合部の 最大曲げ耐力が変形能力に及ぼす影響一塑性歪履歴を受ける鋼 構造柱梁溶接接合部の変形能力(その 1 ), 日本建築学会構造系論文集,第 664 号, pp.1135-1142, 2011.6.

26) 繁栘算男:ベイズ統計入門 第 5 章正規母集団の推論, 東京大学出版, 1985. 27）日下彰宏, 中島正愛：ベイズ更新を利用した震災後の建物安全確認方法 (その 1 ) 問題の定式化, 日本建築学会大会学術講演梗概集, 構造 I, pp.19-20, 2013.8.

28) 大場麻弥，森保宏：地震動のスペクトル特性と部材耐力の不確定性を考 慮した鋼構造骨組の最大変位応答及び簡易応答評価手法に関する研究, 日 本建築学会構造系論文集, 第 73 巻, 第 628 号, pp.859-866, 2008.6.

29) 林和宏, 羅雲標, 林旭川, 倉田真宏, 中島正愛:鉄骨造溶接柱梁接合部の 繰返し載荷挙動一その 1 準静的載荷実験一, 日本建築学会大会学術講演梗 概集，構造 III，pp.795-796, 2013.8. 